\title{
WAGE-EARNER PLANS IN CHICAGO
}

Chapter XIII of the Chandler Act,' entitled "Wage-Earner Plans," provides a mechanism to aid wage earners of lower-income groups in the adjustment and liquidation of their debts. The chapter has been in effect for two years. Advocates of the chapter argued that if the wage-earner debtor were provided with a low-cost means of amortizing his obligations under court supervision and protection, ${ }^{2}$ he would be encouraged to pay his obligations rather than resort to bankruptcy. ${ }^{3}$ While designed to protect the debtors against many of the evils of the present system of debt collection, the chapter provides creditors with a more simple and certain means of collection. The chapter was criticized at the time of its passage on the grounds that it would convert the bankruptcy court into a low-cost collection agency, and, furthermore, that the compulsory nature of the proceeding, once the plan was in effect, amounted to a form of wage slavery. ${ }^{4}$ This study was undertaken to determine to what extent in the Chicago area the chapter has fulfilled its purposes and to what extent the criticisms have proved well founded.

The principal source of information in the study was the files of the cases. From the effective date of the chapter, September 22, I938, to October I0, I940, when the files were examined, I37 petitions under Chapter XIII had been filed. The files in Iog cases were examined, the remainder not being available. Three cases had been closed, two because the debtors had completed payment under their plans, and one because the debtor had died. Only five of the debtors listed assets above the amount allowed as exemption under Mllinois statute; 5 the remainder were "no-asset" debtors. All of the debtors were insolvent, although the chapter provides that the debtor need not be insolvent, but simply unable to pay his debts as they mature. ${ }^{6}$

\section{I}

The wage earner who will resort to the chapter is usually harassed by creditors to the extent that his ability to work is materially impeded. His wages are tied up, and frequently he is threatened with discharge from his employment. To a

${ }_{52}$ Stat. 930-38 (1938), II U.S.C.A. \$ roor-86 (1939). For an analysis of the provisions of the chapter see Wage-Earner Receiverships, 6 Univ. Chi. L. Rev. 459 (I939). For an acute analysis of the social and economic significance of wage-earner bankruptcies see Douglas, WageEarner Bankruptcies-State vs. Federal Control, 42 Yale L.J. 59I (I933).

2 "The court .... shall have exclusive jurisdiction of the debtor and his property, wherever located, and of his earnings and wages during the period of consummation of the plan." $\S 6 \mathrm{Ir}$. Section references are to sections of the Bankruptcy Act of $x 898$, as amended. The United States Code Annotated will not be cited, but the Bankruptcy Act is contained in Title Ix.

3 Report to the President on the Bankruptcy Act and Its Administration in the Courts of the United States (r93I), contained in S. Doc. 65, 72d Cong. Ist Sess. (r932).

4 See Wage-Earner Receiverships, op. cit. supra note $I$, at $463 ; 465$.

5 Ill. Rev. Stat. (1939) c. 52, § I3.

$6 \S 623$. 
person in these desperate straits, Chapter XIII offers prompt relief. Immediately on filing of the petition, the referee issues an order restraining all creditors, secured and unsecured, from attempting to satisfy their claims by resort to wage assignment, garnishment, or repossession.7

After filing of the petition, which contains a schedule of obligations, ${ }^{8}$ each scheduled creditor is notified and requested to attend a creditors' meeting at which the debtor will submit a plan for their approval. Frequently the notices are accompanied by copies of the proposed plan, along with forms for the creditor who desires to consent in advance of the meeting. A majority in number and in the amount of claims of the unsecured creditors may make the plan binding upon the remainder of the class. 9 Only those secured creditors who actually consent are bound..$^{\text {Io }}$ Generally creditors' meetings are poorly attended. Nevertheless, since the plan assures to the creditors a more certain realization of their claims, they are usually willing to consent rather than risk failure of the plan, since, if the plan fails, creditors will individually press collection and force the debtor into ordinary bankruptcy or loss of his job.

Pursuant to the chapter, the plan must provide for periodic payments to a trustee of a portion of the debtor's earnings. ${ }^{x x}$ The plan may provide for a reduction in principal of both secured and unsecured claims. ${ }^{12}$ While the plans under consideration did not generally take advantage of this privilege, every plan did provide for the suspension of interest payments on indebtedness from the date of the filing of the petition. If the debtor has secured the consents of all his creditors, the court must confirm the plan. ${ }^{{ }^{3}}$ On the other hand, if there is only a majority, the court confirms the plan if convinced of its fairness. ${ }^{14} \mathrm{~A}$ trustee is then appointed. ${ }^{\mathrm{I5}}$ The court, under its general powers of supervision of the debtor's earnings, usually enjoins the debtor from contracting any additional debts for the duration of the plan.

The referees in Chicago have been expeditious in their handling of the cases. The length of time between filing of the petition and confirmation of the plan ranged from one and one-half months in one case, to eight months in another, the average time being about three months.

The wage earners in Chicago who resorted to the chapter earned an average

$7 \S 6$ I4. In the case of In re Duncan, C.C.H. Bktcy. L. Serv. 52274 (r940), a district court in Virginia upheld an order of a referee staying the enforcement of a conditional sales contract, in connection with a Chapter $\mathrm{XII}$ proceeding, where the debtor defaulted but agreed to pay the regular monthly installments after confirmation of the plan. The statute provides that the court may stay enforcement of such contracts until final decree, but provides that only such secured creditors as consent to the plan are bound by terms of the plan after confirmation. $\S 652$.

$\begin{array}{lll}8 \S 624(2) . & x 0 \S 652 . & x 2 \S 646 . \\ 9 \S 652 . & 12 \S 646(4) . & \pm 3 \S 65 x .\end{array}$

${ }^{24} \S 652$. In no case where a majority of unsecured creditors had consented to the plan did the court reject the plan as unfair.

${ }^{15} \S 633(4)$. 
of $\$ 1,623$ in the year preceding the filing of the petitions, the amount ranging from $\$ 650$ to $\$ 3,600$, the maximum limit allowed under the chapter. ${ }^{16}$ Total debts listed in the original petitions varied in amount from $\$ 376$ to $\$ 3$, Io6, the average being $\$ \mathrm{x}, 05^{2}$. The debtors listed an average of $\$ 362$ as secured obligations, $\$ 594$ as unsecured, and $\$ 96$ as owed because of the primary obligation of another. The type of debts listed is indicative of the manner in which many debtors became embroiled in their difficulties. In several cases liabilities as an accommodation party constituted a major portion of the indebtedness. ${ }^{17}$ The two principal types of debts were loans from small loan companies and installment purchases from jewelry, clothing, and furniture houses. Among the large group of Negro stockyards workers under the plan, instalment purchases were predominant, while in the remainder of the cases small loans constituted about fifty per cent of the total indebtedness. Where the debtor is obligated to small loan companies, the suspension of interest payments, as provided for in all plans, works a real saving to the debtor, for interest at the rate of three per cent per month as permitted by Illinois statute ${ }^{8}$ would total a considerable sum over the period of the plan. This fact probably constituted a real inducement to many of the debtors to use the chapter.

The privilege of scaling down the debts was utilized in only eighteen cases. The amount of the reduction varied from twenty to fifty per cent, the average being about thirty per cent. The provisions as to scaling down were much more frequent in the first cases filed under the chapter, there having been only four such provisions in the fifty-one cases filed from June 7 to October Io, I940. This may be accounted for either in the reluctance of debtors to seek a reduction, or in the unwillingness of creditors to permit a reduction now that the chapter has been in operation for a time and its effectiveness as a method of collection realized.

One of the leading arguments advanced in favor of the chapter at the time of its passage was the low cost to debtors of the procedure set forth. ${ }^{x 9}$ Fees were set at a minimum figure, and supervision over the allowance of attorney fees was provided for..$^{20}$ In the operation of the chapter in Chicago, however, the costs to the debtor of obtaining relief have been appreciable. Since only three cases have been closed, and of those one because of the debtor's death, final figures on costs could be obtained in only two cases. In one of these cases, the

${ }^{16} \S 606(8)$.

${ }^{27}$ In one case, out of a total indebtedness of $\$ 2,377$, obligations as an accommodation party constituted $\$ r, 689$; in another case these obligations were $\$ 9$ ro out of a total of $\$ x, 157$.

${ }^{8}$ IIl. Rev. Stat. (x939) c. 74, §3x.

I9 See Report of the House Committee on the Judiciary on H.R. 8046, Rep. No. I409, 75th Cong. Ist Sess., at 55 (r937).

${ }^{20}$ Section 624 provides for an initial filing fee of $\$ \times 5$. Section 659 allows payment to the referee and the trustee of their necessary costs and expenses in addition to commissions to the referee of one per cent and to the trustee of five per cent of payments by the debtor. Section 659 also provides for a reasonable attorney's fee, to be set by the court. 
original debt of $\$ 1,058$ as scaled down totalled $\$ 75^{\circ}$. The debtor agreed to pay $\$ 80$ per month. The attorney's fee in the case was \$Ioo; the trustee received a total of $\$ 88.48$, including $\$ 45.48$ as his commission of five per cent of the funds handled, \$Io for his bond, \$I4.5० as bank charges, and \$I8.50 as stenographic expenses. The referee's office received a total of $\$ 57.3 \mathrm{I}$, including $\$ 37.25$ as the aggregate of various filing fees, $\$ 9.06$ as the referee's commission of one per cent of the funds, and $\$ I I$ as necessary costs. In the process of paying $\$ 75^{\circ}$ to creditors, this debtor paid a total of $\$ 245.79$ as expenses, or approximately thirty-five per cent. In the other case, the original schedule listed debts totaling $\$ 1,278$. Creditors having only $\$ 972$ in claims participated in the plan and these debts were scaled down to $\$ 648.60$. The attorney received $\$$ I50, the referee $\$ 34.02$, and the trustee $\$ 95 . I x$, the total costs being $\$ 279.13$. The costs in this case aggregated forty-three per cent of the amount paid to creditors. Attorney fees in pending cases ranged from $\$ 35$ to $\$ 200$, usually in proportion to the amount of indebtedness, and averaged about \$95, somewhat less than the fees in the above two cases.

The monthly payments to be made by the debtor varied from twenty to fifty per cent of his wages, or from $\$ 20$ to $\$ 80$ per month. Thus, decided advantage to creditors under the plan may be seen in the percentage of income which the debtor was to pay. Under present Illinois law, ${ }^{2 I}$ creditors may take an aggregate of only twenty-five per cent of the debtor's wages through wage assignment and garnishment. Since the court in its supervision of the proceedings supposedly guarantees an adequate income to the debtor, the larger payments do not necessarily work hardship on the debtor.

The only provision in the chapter as to the duration of plans is a negative one:

If at the expiration of three years after the confirmation of a plan the debtor has not completed his payments thereunder, the court may ...., if satisfied that the failure of the debtor to complete his payments was due to circumstances for which he could not be justly held accountable, enter an order discharging the debtor from all his debts and liabilities provided for by the plan. ....22

Under the plans studied, the time necessary to complete payment varied from seven months to four years and seven months; the average duration was a little over two years. ${ }^{23}$ In twelve of the cases, however, the plan was to run for more than three years. The question may be raised whether these latter cases are not contrary to the spirit of the provision set forth above. To allow such an extension of the plans would seem to give weight to the criticism leveled at the chapter, that it would provide for a type of wage slavery. Inasmuch as the

${ }^{2 x}$ Ill. Rev. Stat. (1939) c. 74, $\S 35$. $22 \S 66 x$.

${ }^{23}$ The basis of this computation was the amount of the originally listed indebtedness, as scaled down, and the amount of the monthly payments authorized by the plan. No account was taken of possible further reduction in principal through failure of creditors to prove or file claims, or refusal of some secured creditors to participate. 
chapter permits alteration in the plans to meet changing conditions of the debtor, ${ }^{24}$ the section quoted above might be construed to mean that the plan should extend more than three years only if emergencies in the circumstances of the debtor should arise which would warrant such an extension. ${ }^{25}$

\section{II}

In appraising the operation of Chapter XIII in Chicago, reference should be made to the possible alternative types of relief available to the debtor and to the operation of the plan in other areas. Closely related to the type of relief given under the chapter is the work of private amortization companies. The record of one of several such companies ${ }^{26}$ operating in Chicago may serve to illustrate the type of service they render. From May I, I939, to May I, I940, during which time Chapter XIII was in effect, the company closed 448 accounts. The average income of the persons whose debts were amortized was \$I, 596 a year, approximately the same as that for the Chapter XIII debtors. The average debt was $\$ 565$, as compared to $\$ 1,052$ under Chapter XIII. The average fee charged was $\$ 65$, or Ir. 5 per cent of the initial indebtedness. Liquidation failed in 23.2 per cent of the cases. Although for their duration these plans are purely voluntary with the debtor, the fact that failure to complete the plan would probably bring about loss of the debtor's job is sufficient pressure on the debtor to complete the plan. Since all creditors must consent to a private plan, scaling down provisions are infrequent, although most plans do provide for suspension of interest payments.

More extensive use has been made of Chapter XIII in several other jurisdictions, notably in the federal district court in Birmingham, Alabama. ${ }^{27}$ For several years prior to the passage of the present bankruptcy act, the court there used Section 74 of the old act ${ }^{28}$ to accomplish practically the same results as the present chapter allows. In a period of three months in I939, under the present act, a total of 438 petitions were filed under Chapter XIII. The costs in Birmingham have been kept much lower than in Chicago; besides the filing fee of $\$$ I 5 , referee's costs have been held down to $\$ 8$, the average attorney's fee has been about $\$$ I 5 , and a fee of six per cent of the total funds handled has been found sufficient to meet the costs of a "supervisor," a full-time court official who acts as trustee in all the cases. The total costs to a debtor owing $\$ 600$ would

$24 \S 646(5)$.

${ }_{25}$ Section 75 of the proposed Hastings-Michener Bill provided that the plan should never exceed two years. That bill was never reported out of committee, but $\S 75$ furnished the pattern for the present Chapter XIII. See Report of the House Committee on the Judiciary, note I9 supra, at 53 .

${ }^{26}$ Financial Adjustment Co., I05 W. Madison St., Chicago, Ill.

27 For a more detailed discussion of the operation of the chapter in Birmingham, see Woodbridge, Wage Earners' Receiverships, 23 J. Am. Judicature Soc. 242 (1940). This article also contains a study of the operation of the Michigan Wage-Earner Receivership Law.

${ }^{28} 47$ Stat. 1467 (I933), as amended by 48 Stat. 922 (I934) and 49 Stat. 246 (I935), II U.S.C.A. $\$ 202$ (1937). 
be $\$ 74$, or I2.3 per cent. This amount, although slightly more than that charged by the private amortization companies in Chicago, is much less than the cost of Chapter XIII proceedings in Chicago.

The explanation for the difference in costs in the two cities is probably to be found, first, in the greater efficiency with which the cases are handled in Birmingham, and, second, in the differential in the cost to a lawyer or referee of maintaining an office in the two cities. The procedure in Birmingham seems to be less formal than that in Chicago; furthermore, there is probably more work to be done by the lawyer in the Chicago cases, where the situation of the average debtor is apparently more critical than that of the Birmingham debtor. ${ }^{29}$

\section{III}

Chapter XIII was predicated, in part, on the belief that wage earners, who constitute a considerable proportion of all bankrupts, approximately fifteen per cent in 1938 and $1939,{ }^{30}$ were driven into bankruptcy chiefly by the pressure of garnishments and wage assignments, and that many who were forced into bankruptcy could and would pay their creditors in full if given time and protection. In the light of the fact that out of a total of approximately 3,700 cases in the bankruptcy docket in Chicago in the two years during which the Chandler Act has been in effect, only I37 cases were under Chapter XIII, the expectations of the sponsors do not seem to have been realized, at least in so far as the use of the chapter in Chicago is concerned.

Several reasons for the dearth of cases in Chicago may be suggested. Undoubtedly, unwillingness to commit themselves to the supervision of a court for a term of years played a decisive role in the choice of the relief sought by many debtors. Nevertheless, the relatively wide use of private amortization companies, whose supervisory procedure is similar to that of the courts, indicates that the higher costs of a proceeding under the chapter may have been a consideration of some weight. This deficiency in the operation of the chapter can probably be remedied to some extent by the adoption of a more routine procedure for the handling of cases, similar to that used in Birmingham. Wider recognition should be given, moreover, to the savings which are latent in the privilege granted by the chapter to suspend interest payments and to scale down. the amount of indebtedness. A further reason for the small number of cases may possibly be found in the absence of adequate legal advice available to the improvident debtor; while the phenomenon of bankruptcy is well known to the public generally, the existence of Chapter XIII is probably not so well known, and frequently the alternative procedure may not be presented to the debtor for choice.

${ }^{29}$ See Woodbridge, op. cit. supra note 27 , at 277 .

${ }^{30}$ See Annual Report of the Attorney General 246-47 (I938); and the r939 report, at 23I33. See also Report of the House Committee on the Judiciary, note r9 supra, at 54, where it is said that farmer and wage-earner bankruptcies constitute over fifty per cent of all bankruptcy cases. In r932, for example, there were 34,579 farmer and wage-earner bankruptcies in a total of 63,502 cases in the United States. U.S. Att'y Gen. Ann. Rep. 247 (I932). 
Debtors who have resorted to Chapter XIII in preference to other proceedings have acted from a variety of motivations. Private amortization plans may have been unavailable because of the high amount of the indebtedness or because a sufficient number of consents could not be obtained to make a voluntary plan feasible. Others preferred Chapter XIII, possibly, because of the moral stigma reputedly attached to ordinary bankruptcy. On the other hand, the explanation of those in closest contact with the administration of the chapter was that a large majority of the Chapter XIII debtors would have been unable to obtain discharge in an ordinary bankruptcy, either because of a prior discharge within the preceding six years or because of the issuance of a false financial statement. ${ }^{3 x}$ Although the records disclosed that only twenty-two of the debtors who resorted to Chapter XIII would have been barred from bankruptcy because of prior discharge, an indefinite number of others would possibly have been barred because of false financial statements.

The question necessarily arises whether a debtor is entitled to relief under Chapter XIII if he is barred from ordinary bankruptcy for one of the above reasons. The chapter provides: "The court shall confirm a plan if satisfied that .... (4) the debtor has not been guilty of any of the acts or failed to perform any of the duties which would be a bar to the discharge of a bankrupt....." ${ }^{2}$ The language of the statute apparently forbids relief under the chapter where it could not be obtained in ordinary bankruptcy. It may be argued, however, that Chapter XIII operates merely as an extension of indebtedness, with all unsecured creditors treated as a class, bound by the decision of a majority; as to secured creditors, the voluntary nature of the plan is apparent. On the other hand, the power of the court to grant a discharge from all debts remaining after three years indicates that the chapter has some characteristics of ordinary bankruptcy. The referees in Chicago are acting on the assumption that a bankrupt is nevertheless entitled to relief under Chapter XIII within the six years after a discharge. ${ }^{33}$ An appeal from one of these rulings is now pending before the district court. ${ }^{34}$

$$
{ }^{31} \S \mathrm{I} 4 \mathrm{c} \text {. } \quad 32 \S 656 \text {. }
$$

${ }_{33}$ The referees in Birmingham appear to be acting on the same assumption. See Woodbridge, op. cit. supra note 27, at 277. A district court in New York has recently decided that the issuance of a false financial statement is a bar to relief under Chapter XIII. In re Post, C.C.H. Bltcy. L. Serv. 52670 (D.C. N.Y. I940). Under the old $\$ 74$ composition, courts were divided whether a debtor could obtain relief by bankruptcy or composition more than once in six years. See Rosenberg v. Borofsky, 295 Fed. 500 (C.C.A. 1st 1924) (where the court held a composition within the preceding six years barred a discharge in bankruptcy); In re Goldberg, 53 F. (2d) 454 (C.C.A. 6th 193I) (composition within six years was not a bar to another composition); and see In re Greenman, ro F. Supp. $45^{2}$ (Me. r935) (discharge in preceding six years was a bar to composition). The statute at that time provided: 'The court shall confirm the proposal [composition] if satisfied that .... (3) the debtor has not been guilty of any of the acts, or failed to perform any of the duties, which would be a ground for denying his discharge." 47 Stat. I 467 ( $(933)$ ), as amended by 48 Stat. 922 (1934) and 49 Stat. 246 (1935), II U.S.C.A. § 202 (g) (I937).

34 In re Nathan, Bankruptcy Docket, U.S. D.C. N.D. Il., No. 72936. 
In its larger social aspect, the question of whether Chapter XIII or ordinary bankruptcy represents a more desirable type of relief is a significant one. If the admittedly paternalistic provisions of the chapter, providing for strict court supervision of the economic life of the debtor for a period of years under the plan, are to be retained, the question of whether the discharged debtor will revert to his former habits is an important one. The hope of Chapter XIII lies in the conviction that, if a man is helped to pay his debts, but at the same time is made to suffer for his former improvidence by full payment, he will learn a lesson in the management of his finances and will not allow himself to face the same situation again. It is generally admitted that the relief given under ordinary bankruptcy has not achieved that purpose. The question whether Chapter XIII will achieve the desired result cannot be answered until the chapter has been in effect for a longer time, and then only if a larger number of cases are handled.

\section{APPEALABILITY OF INTERLOCUTORY ORDERS OF INDEPENDENT FEDERAL ADMINIS- TRATIVE AGENCIES}

While much of current controversy over administrative adjudication is concerned with limitations on the scope of judicial review of administrative findings of fact, ${ }^{x}$ difficulties have also arisen with respect to the time at which judicial review should be available. ${ }^{2}$ The "final order" rule today operates to prevent court review of administrative determinations until the final stage of an administrative proceeding has been completed. The irreparability at that time of injuries which litigants may have sustained in the course of proceedings suggests that so inflexible a rule may be undesirable. ${ }^{3}$ It is here proposed to examine the cogency of this criticism and to indicate the feasibility of permitting interlocutory appeals from certain determinations of independent federal administrative agencies. It is believed that such a course can be adopted, moreover, without serious impairment of administrative efficiency. The increased protection of private rights which this will afford may serve to alleviate some of the bitterness with which at present the business community regards the administrative process.

The constitutional requirement of "case or controversy" imposes a decisive restriction on the type of administrative rulings which may properly be brought

× For example, McDermott, To What Extent Should the Decisions of Administrative Bodies Be Reviewable by the Courts?, 25 A.B.A.J. 453 (I939); Landis, Administrative Policies and the Courts, 47 Yale L.J. $5^{\text {I9 }}$ (I938); Cooper, Administrative Justice and the Role of Discretion, 47 Yale L.J. 577,588 et seq. ( 1938 ).

2 For a general discussion of the "time" problem see Appealability of Administrative Orders, 47 Yale L.J. 766 (I938).

3 Examples of interlocutory orders which may injure litigants are to be found in Crick, The Final Judgment as a Basis for Appeal, 4I Yale L.J. 539, 545 et seq. (I932). 